\title{
Ocean Energy
}

\author{
M RAVINDRAN* and V S RAJU \\ Formerly at: Ocean Engineering Center, IIT Madras, Chennai, India
}

(Received on 30 March 2014; Accepted on 12 August 2015)

\begin{abstract}
Ocean energy is an important and promising renewable energy for the future. Even though extensive technology development and demonstrations have occurred in the areas of ocean thermal energy, wave energy and tidal energy over the last 40 years, commercial plants based on these technologies are very slow in coming up because of the high capital costs. In recent years, due to increase in the fossil fuel costs, renewable energies such as solar photo voltaic systems and wind energy systems have become cost competitive. Ocean energy systems are likely to become cost competitive in a decade or so, especially for remote islands and coastal areas. This chapter presents the highlights of developments in the areas of ocean thermal energy, wave energy and tidal energy.
\end{abstract}

Keywords: Ocean Energy; Ocean Thermal Energy; OTEC; Open Cycle and Closed Cycles for OTEC; Wave Energy; Oscillating Water Column; Tidal Energy

\section{Ocean Energy}

Ocean energy, which is an indirect form of solar energy, is a very large resource. The development and demonstration of ocean energy technology has been suffering all along because of high cost of plant structures and offshore infrastructure. The sharp increase in the oil prices has highlighted, once again, the need to develop large-scale renewable energies including ocean energy.

The three forms of ocean energy conversion systems which have reached already a "technology demonstration" or "pre-commercial" phase are:

i. Ocean thermal energy conversion (OTEC)

ii. Wave energy conversion (WEC)

iii. Tidal energy conversion (TEC)

The highest priority of ocean technologists today is to reassess the techno-economic viability of ocean energy plants vs fossil fuel plants, in the context of high oil price and the available carbon credit.
The potential of ocean energy in different regions depends on their geographical location with respect to the equator. Countries closer to the equator having tropical seas around them have good potential for OTEC and countries in northern and southern latitudes have a good potential for wave energy. Tidal energy, caused by gravitational pull of moon and sun on the ocean mass of water, is high only in estuaries and bays where the tidal oscillations are amplified.

\section{Ocean Thermal Energy Conversion \\ Regional Availability and Current Status}

OTEC utilizes the temperature-difference between warm surface sea water of around $27-29^{\circ} \mathrm{C}$ in tropical waters and the cold deep sea water of around $5-7^{\circ} \mathrm{C}$, which is available at a depth of 800 to $1000 \mathrm{~m}$, to run a heat engine under Rankine cycle. This temperature differential worldwide and typical temperature depth profiles are shown in Fig. 1 (Ravindran, 2010).

The warm surface water exchanges energy with low temperature boiling fluids such as ammonia and

*Author for Correspondence: E-mail: ravinmv@gmail.com 


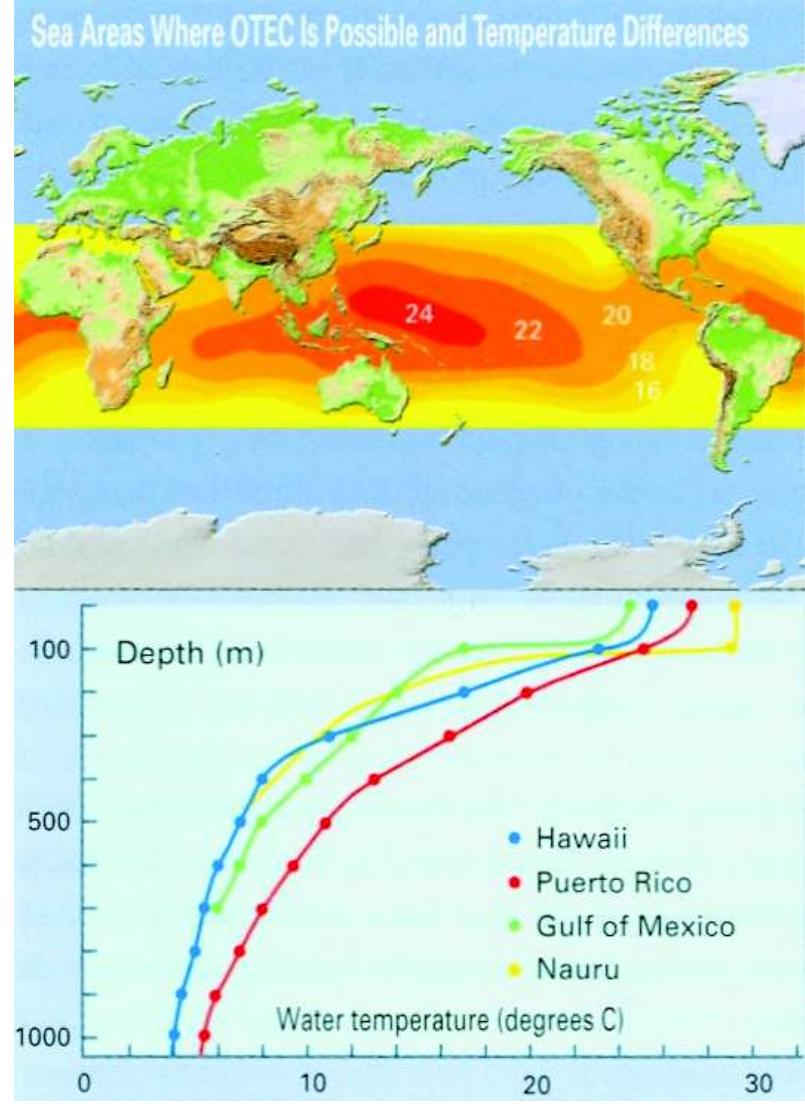

Fig. 1: Temperature variation with depth of the sea. (Source: Ravindran 2010)

the vapour generated is passed through a turbine to produce work. The vapour, after expansion in the turbine, is condensed using deep sea cold water and re-circulated. This is how a closed cycle OTEC plant, which can easily be scaled to MW range, operates. In the Asia and Pacific Region, Japan and India are the only countries actively involved in OTEC research and there are a large number of islands which are ideally suited for OTEC plants. In these islands, the deepwater is close to the shore and facilitates the installation of shore-based OTEC plants. India started research in the Lakshadweep and Andaman Nicobar region (Ravindran, 1999).

In an open cycle system, warm surface sea water at $28^{\circ} \mathrm{C}$ is flash evaporated in a vacuum chamber. The ensuing low pressure steam drives a fairly large diameter turbine and is condensed by circulating the cold deep sea water. The condensate is potable water which is also valuable. However, the closed cycle OTEC plant is more compact.

A number of OTEC technology demonstration plants have been tested across the world from the late 1970s (Avery, 2002), as listed in Table 1.

India with its vast potential of OTEC resource started feasibility studies of 1MW land-based OTEC plants in 1982.Later in the mid-90s, the National Institute of Ocean Technology, Chennai, India, (NIOT) started the design and construction of a 1MW floating plant with a closed cycle ammonia system. Even though the barge and onboard systems were tested, (Manivannan et al., 2003), the whole plant could not be commissioned due to the failure of the flexible joint between the barge and the $1000 \mathrm{~m}$ long cold water pipe. Subsequently, NIOT applies the open cycle OTEC principle for the desalination purpose using cold water drawn from $600 \mathrm{~m}$ depth and warm surface water at $29^{\circ} \mathrm{C}$. A desalination plant of 0.1 million litre

Table 1: Summary of OTEC demonstration plants

\begin{tabular}{|c|c|c|c|c|c|c|}
\hline \multirow[t]{2}{*}{ S.No. } & \multirow[t]{2}{*}{ Agency/Name } & \multirow[t]{2}{*}{ Year, location } & \multicolumn{2}{|c|}{ Power rating $(\mathrm{kW})$} & \multirow[t]{2}{*}{ Cycle } & \multirow[t]{2}{*}{ Type of plant } \\
\hline & & & Gross & Net & & \\
\hline 2. & Mini OTEC (US) & 1979, Hawaii & 53 & 18 & Closed (Rankine) & Floating \\
\hline 3. & OTEC-1 (US) & 1980, Hawaii & 1000 & - & Closed (Rankine) & Floating \\
\hline 4. & Toshiba \& TEPC (Japan) & 1981, Nauru & 120 & 31.5 & Closed (Rankine) & Shore-based \\
\hline 5. & Japanese Mini OTEC & 1979, Japan & $100 \mathrm{kWe}$ & - & Closed & Floating \\
\hline 6. & NELHA (US) & 1992, Hawaii & 210 & 40 & Open & Shore-based \\
\hline 7. & Saga University (Japan) & 1984, Saga & $75 \mathrm{~W}$ & - & Closed (Rankine) & Lab model \\
\hline
\end{tabular}


capacity daily is successfully operating at Kavaratti, in the Lakshadweep islands for the last 3 years. Later, in 2007, a floating desalination plant with a capacity of 1 million litres of fresh water daily was demonstrated at 1000m depth off Chennai (Ravindran et al., 2007). The climatic conditions required for the operation of an OTEC plant are satisfied in about 100 countries.

\section{Current Technologies}

There is a need to reduce the cost of OTEC plants, with a medium output of 10-40 MW. The major cost of a closed cycle OTEC plant comes from the cost of heat exchangers, the floating barge and the $1000 \mathrm{~m}$ deep cold water pipe system. Compact titanium plate heat exchangers plates used in the Indian plants have been coated with stainless powder to enhance the heat transfer coefficients. Almost all the OTEC demonstration plants have used cold water pipes made of HDPE. The new experience in offshore oil has introduced the concept of flexible steel riser pipes which are likely to reduce the cost of deployment.

\section{Merits and Demerits of Open Cycle for OTEC}

Merits : Open cycle does not deal with any fluids (such as ammonia or freon), which are not environment-friendly. Water is the working fluid and the condensate exiting from the system is potable water.

Demerits : Since the turbine handles very low pressure steam (.02 bar), the size of the turbine is very large. Hence, open cycle is useful only for low ratings.

\section{Merits of Closed Cycle OTEC}

Since working fluids such as ammonia/freon are enclosed in a sealed system under pressure (approx. 6 to 8 bar), the size of the turbine is compact. Closed cycle OTEC is suitable for large commercial plants.

\section{Wave Energy}

\section{Regional Availability and Current Status}

The potential of wave power in wind generated waves is
$P=0.55 H^{2}{ }_{\mathrm{s}} T_{\mathrm{z}}(\mathrm{kW}$ per metre of wave crest length),

where $H_{\mathrm{s}}=$ Significant wave height of random waves in metres.

$$
T_{\mathrm{z}}=\text { Zero crossing period in seconds. }
$$

Normally, this potential is 10 to $15 \mathrm{~kW} / \mathrm{m}$ in countries lying between $\mathrm{N}$ and $\mathrm{S} 10^{\circ}$ latitudes. For regions in higher latitudes, the potential varies from 20 to $70 \mathrm{~kW} / \mathrm{m}$ (Thorpe, 1999). Most of the countries including island nations possess this potential. Even though energy from waves has less variability compared to wind energy, the actual wave power varies from time to time and from season to season. The offshore devices have higher potential because deep water waves possess higher energy.

Japan was the first nation to use wave power, almost 50 years back, for application in navigational buoys (Masudaand Miyazaki, 1978). The UK started serious research on a variety of devices during the mid-70s. During the early 1980s, Japan, other countries in Europe such as Norway, Sweden and Portugal started testing a variety of devices.

India, China, Korea, Australia and USA joined the group during the mid-80s. Thorpe (1999), Muetze et al., (9)* and Brooke, (2003) have provided a review of all these devices and technology demonstration studies.

Among all devices, the oscillating water column (OWC) device was the most often studied and tested by many countries in Europe and Asia (see Fig. 2).

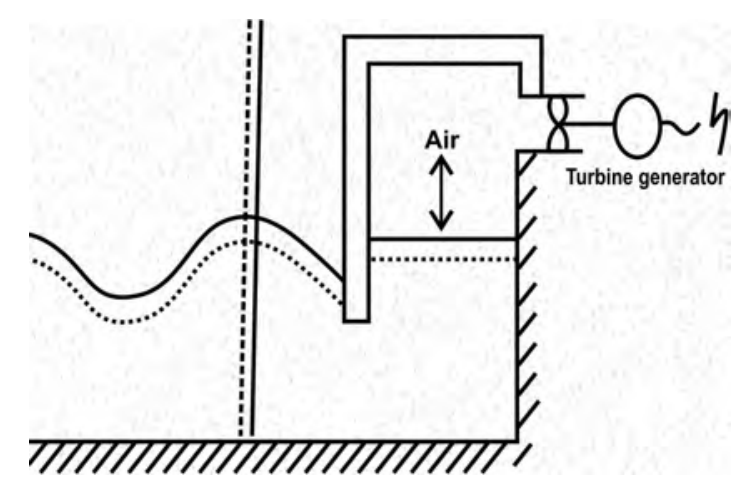

Fig. 2: Oscillating water column

*The number refers to the website reports given under references 
The OWC device has a submerged opening through which waves enter a chamber, the wave oscillates the water level inside the chamber and causes bidirectional airflow in and out of the chamber. The power take-off system consists of an air turbine and generator. There has been a variety of turbines developed with flow rectifying valves and without valves. The turbine types varied from the Wells type (Raghunathan, 1985) to impulse turbines (Setoguchi, 2001, Santha Kumar et al., 1998). Similarly, different types of generators/controls were also developed (Ravindran et al., 1997). The OWC-based plants built in Japan, Norway, UK, Portugal and India have demonstrated the technical feasibility of generating electricity from waves, but with output power in the range of few hundred kilowatts only. The plant erection and operational costs were high. However, if scaled up to multiple megawatts, the cost is expected to be around 8 cents (U.S)/kWh (Thorpe, 1999).

\section{Current Technologies}

The most promising device with large capacities for shoreline applications is the bottom-standing OWC device. Field experiments have been conducted on systems of varying capacities, namely, $30 \mathrm{~kW}$ unit at Kujukuri, China, a $60 \mathrm{~kW}$ unit at Sakata port in Japan; $75 \mathrm{~kW}$ unit at the island of Islay, Scotland, a $150 \mathrm{~kW}$ unit at Trivandrum, India, $500 \mathrm{~kW}$ unit at Toftes fallen, Norway and at the island of Pico, in Azores in Atlantic Ocean.

Table 2: Promising offshore wave energy devices
Thorpe (1999) has listed the following four promising wave energy devices for use as offshore devices in water depths of more than $40 \mathrm{~m}$ (Figs. 35 ). The offshore devices mainly consist of vertically heaving submerged buoys or multiple floating bodies hinged together.

\section{Emerging Technologies}

The coastal regions and islands mostly need to augment drinking water supplies. Hence, the wave energy devices are also being used to desalinate sea water. The Indian OWC plant with its installed capacity of $50 \mathrm{~kW}$ was used to run an R.O. plant supplying 10,000 litres of fresh water to a nearby fishing village (Sharmila et al., 2004). Carnegie Corporation, Perth, Australia is planning to install an array of submerged heaving buoys to pump sea water to a Pelton wheel for power generation up to $300 \mathrm{MW}$ in addition to a R.O.-based desalination plant (7). Three units of Pelamis device have been tested in a wave farm in Portugal during 2007 with a total capacity of $3 \times 0.75$ MW and the technology is being offered for worldwide use. Pelamis has received a venture capital US \$ 68 million for this development (8).

\section{Potential Regional Applications}

In the Asia Pacific region, the south western Australian coast has the highest wave energy potential of $40-70 \mathrm{~kW} / \mathrm{m}$. Japan and other island nations in the region with a wave power potential of $15-40 \mathrm{~kW} / \mathrm{m}$ can choose between shoreline devices or offshore devices depending on the sites. In India, the achievable

\begin{tabular}{|c|c|c|}
\hline Device & Concept & Unit rating \\
\hline McCabe Wave Pump & $\begin{array}{l}\text { Three pontoons hinged across their beam. Relative movement at } \\
\text { hinges pressurizes a liquid which drives a hydraulic motor - generator }\end{array}$ & $\begin{array}{l}40 \mathrm{~m} \text { long device - power } \\
400 \mathrm{~kW} \text { - tested off Ireland }\end{array}$ \\
\hline $\begin{array}{l}\text { Ocean Power } \\
\text { Technology WEC }\end{array}$ & Heaving motion of a buoy converted into mechanical power & $400 \mathrm{~kW}$ - tested off Ireland \\
\hline Pelamis Device & $\begin{array}{l}\text { Cylindrical sections linked by hinged joints. Relative movement at } \\
\text { these joints develops high pressure liquid driving a hydraulic motor - } \\
\text { generator system }\end{array}$ & $\begin{array}{l}\text { A } 130 \mathrm{~m} \text { buoy device has a } 375 \mathrm{~kW} \\
\text { rating }\end{array}$ \\
\hline $\begin{array}{l}\text { Archimedes Wave } \\
\text { Swing }\end{array}$ & $\begin{array}{l}\text { A cylindrical air filled chamber is moving up and down due to action } \\
\text { of waves - this movement is used for power generation }\end{array}$ & $\begin{array}{l}\text { Typical diameter of chamber } \\
10-20 \mathrm{~m}\end{array}$ \\
\hline
\end{tabular}

Source: Thorpe (1999) 


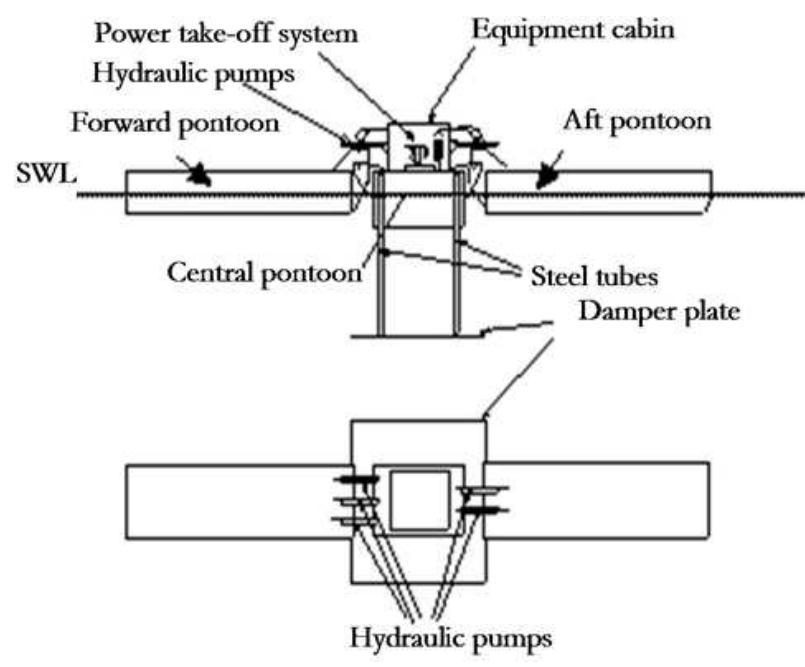

Fig. 3: McCabe wave pump

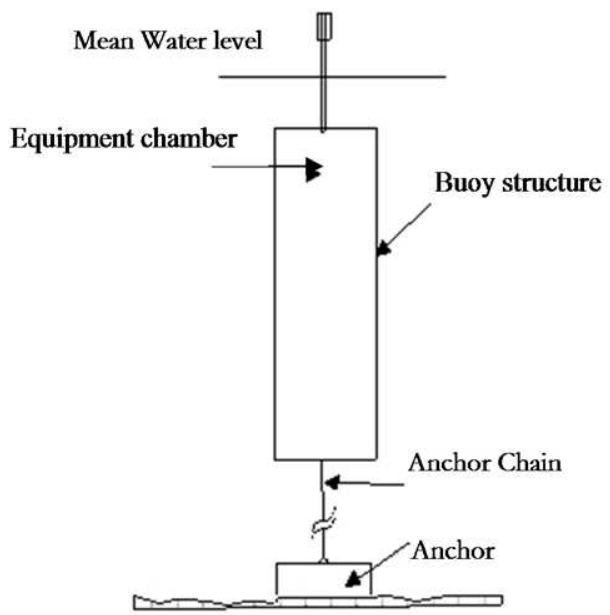

Fig. 4: The OPT WEC

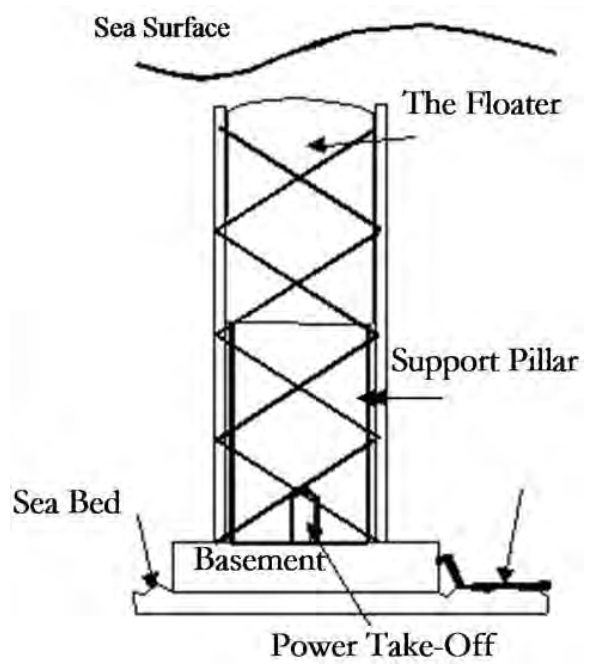

Fig. 5: The Archimedes wave swing resource from wave energy is estimated to be 20,000 MW (Ravindran et al., 2007).

\section{Tidal Energy Conversion \\ Regional Availability and Current Status}

Tidal power plants use the gravitational pull of the moon on the ocean mass of water. The mass of water within the boundary of estuary goes through higher oscillations on being excited by the tidal waves in the open ocean. Wilson (1973) studied the tidal power potential at many locations in Europe and Asia and highlighted its promise.

The water level difference between the open ocean and bay/estuary causes tidal flows with higher velocities. Tidal power can be generated by allowing the water to flow through turbines located in the barrage separating the estuary from the sea or by allowing the tidal current to directly drive the freely located turbines in the creeks or the channels. If the turbines are provided with casings/shrouds, then power developed could be 3 to 4 times the power from an open flow or free stream turbine.

Locations suitable for tidal power are few in each country.

Among all the forms of ocean energy, tidal energy was the first to be exploited on a large scale. The Rance tidal plant, commissioned in 1966, with a barrage across the Rance river estuary in France, has an installed capacity of $240 \mathrm{MW}$ with 24 bulb turbines of capacity $10 \mathrm{MW}$ each. The plant is working efficiently even today. There were smaller tidal power plants built at Kislaya Guba in Russia and at Bay of Fundy in Canada. China has built 10 mini tidal plants with a total capacity of $20 \mathrm{MW}$. Many tidal current turbines have been installed and are operating successfully at many locations in the world.

\section{Current Technologies}

The barrage of the Rance power plant is similar to a barrage in a low head hydropower plant. However, the cost of construction was very high, since the barrage had to be built in the ocean. Subsequent tidal power plants prefer using pre-fabricated concrete 
caisson technologies to reduce the cost of construction in the sea (Sharma, 1983). In smaller power plants, free stream turbines are preferred.

\section{Emerging Technologies}

The main aim of future tidal power plants is to reduce installation cost and to maximize power output. Shrouded turbines or free-standing turbines located in a duct are most promising in this direction (2).

\section{Potential Regional Applications}

India has tidal power potential of around 20,000 MW mainly from the two states of Gujarat and West Bengal. The Gulfs of Cambay and Kutchch in Gujarat have a peak tidal range of $11 \mathrm{~m}$ and the current velocities reach about $5 \mathrm{~m} / \mathrm{s}$. A number of feasibility studies have been conducted. The Sundarban region in west Bengal has a tidal range of around $5 \mathrm{~m}$. In December 2007, the Government of India has announced the approval to build a tidal power plant of 3.65 MW capacity in the Durgaduani creek of Sundarban area at a cost of US \$ 12 million (3).

South Korea is building a small tidal power plant of $1 \mathrm{MW}$ capacity at the Myeongnyang channel, South Jeolla province. Also planned are a $252 \mathrm{MW}$ plant at Gari Island (4), and a 812 MW plant in Ganghwa region (5). China is designing a plant of $300 \mathrm{MW}$. New Zealand is planning a tidal current power plant at Kaipura Harbour with 200 free stream turbines with a capacity of $60 \mathrm{MW}(6)$. North West Australia has high tidal power potential. The resource in Derby region alone is $3000 \mathrm{MW}$. A $50 \mathrm{MW}$ tidal power plant is being planned there (1).

\section{Closure}

Tidal energy has large potential and the technologies are proven. We are likely to see commercial tidal power plants soon. There is a need for innovations to reduce the cost of civil works. Increase in energy costs of conventional sources and concerns related to greenhouse gases would give an impetus to tidal power plants.

\section{Areas for Research}

\section{Ocean Thermal Energy Conversion}

The main requirements are to reduce cost of installation per MW output and to increase income by providing additional byproducts. The following research areas are suggested:

- Develop cheaper and lighter materials such as aluminium alloy to replace costly titanium plates. Heat exchangers contribute to about $30 \%$ of the total plant cost.

- One of the critical technology challenges is the interface between the floating barge and the $1000 \mathrm{~m}$ long cold water pipe. Studies on flexible steel risers and inflatable risers with deep water submersible pumps mounted at the bottom end of the inflatable cold water pipe will help to reduce the cost of cold water pipes.

- Innovative designs for the floating platform and their mooring devices by adapting the recent designs from offshore oil platforms to reduce the capital costs.

- By providing valuable byproducts such as fresh water, hydrogen and exotic species from aquaculture using cold deep sea water effluent will enormously improve the economics of the plant. Studies on nutrients in deep sea water and their impact on aqua culture will enhance the total income from OTEC plants.

- $\quad$ The cable for transmitting power from floating OTEC plants to shore is also an expensive component of the plant. Efforts are needed to develop cheaper and reliable cables for largescale power transmission in deep water applications.

\section{Wave Energy Conversion}

Major challenges in WEC system are the cost reduction of the supporting structures. To address these issues, the following research areas are suggested: study of breaking wave forces on shoreline devices and optimizing the structural design with innovative construction techniques; and fatigue 
analysis, corrosion and wear analysis of all mechanical parts exposed to wave action. A variety of materials have to be studied so that long-term reliability could be ensured at a reasonable cost.

\section{Tidal Energy Conversion}

A major cost component of a tidal power plant is the civil engineering construction cost of the barragebased plants. In free stream tidal current plants, the operating efficiency of turbines without shrouds/casing ducts need to be enhanced. To address these points, the following research areas are suggested:

- Studies on cheaper designs and their deployment procedures for prefabricated caissons to be used in the barrage construction.

- Performance studies on variety of turbine designs/blade profiles to ensure high efficiency.

Apart from the three areas suggested for energy conversion, two more important areas common to all the three energy systems are:

- Conduct updated techno-economic analysis of the ocean energy plants to compare them with other fossil fuel plants using the current cost of fossil fuels.

- Conduct surveys for assessing the potential from the three ocean energy sources and create awareness among policy makers, for funding technology demonstration and later commercialization of ocean energy in countries of the Asia-Pacific region.

\section{Indian Contributions}

The main Indian contributions are in the areas of wave energy, OTEC and its spin-off desalination.

\section{Wave Energy}

Sponsored by Department of Ocean Development, a $150 \mathrm{KW}$ wave energy pilot plant, 3500 ton concrete structure, a first of its kind in the world, was built at Vizhinjam by IIT Madras. The National Institute of Ocean Technology (NIOT) took over the plant in 1996. Several power modules were tested. A fixed blade impulse turbine connected to a variable speed alternator gave the best efficiency. The generated power was also used to run a RO-based desalination plant of capacity 10,000 litres per day. The capability for the construction, operation and maintenance of the plant was demonstrated. What was not assessed correctly was the matching of the turbine characteristics with that of the OWC. Hence, while power was generated successfully, efficiencies were poor. Breakwater-integrated OWC modules may still prove to be economical in the context of modern day construction.

\section{Ocean Thermal Energy Conversion}

In 1998, NIOT embarked on setting up a 1 MW floating OTEC plant in $1000 \mathrm{~m}$ water depth about $40 \mathrm{~km}$ off Tuticorin in South India. The major challenge was the design of the platform and cold water pipe. A nonself-propelled barge was designed with special features such as three moon pools and a retractable cold water sump to suit the requirements of the pumps. The barge was built in a shipyard on the west coast of India and named "Sagar Shakthi". A cold water pipe of length $1 \mathrm{~km}$ and diameter $1 \mathrm{~m}$ was joined by thermal fusion at the Tuticorin port and towed $40 \mathrm{~km}$ offshore where $1000 \mathrm{~m}$ water depth was available.

Sufficient offshore handling facilities were not available; hence, the deployment had to be carried

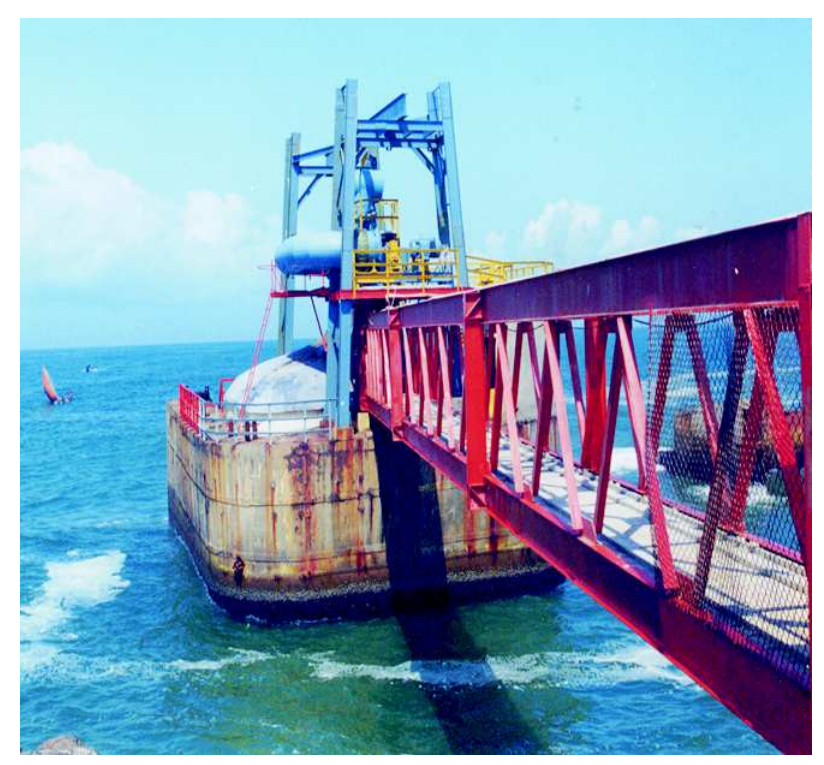

Fig. 6: Wave energy power plant at Vizhinjam. Source: Ravindran (1997) 
out with serous limitations. Twice with two different pipes/mooring systems, lack of infrastructure and rough weather conditions, loss of the pipeline occurred. Hence, the project could not be completed. Later the same barge was used for mounting the desalination equipment and fresh water was first generated in shallow water.

The OTEC project led to extensive capacity building, as everything was designed in-house and attempted with mostly indigenous equipment. The experience led to success in desalination.

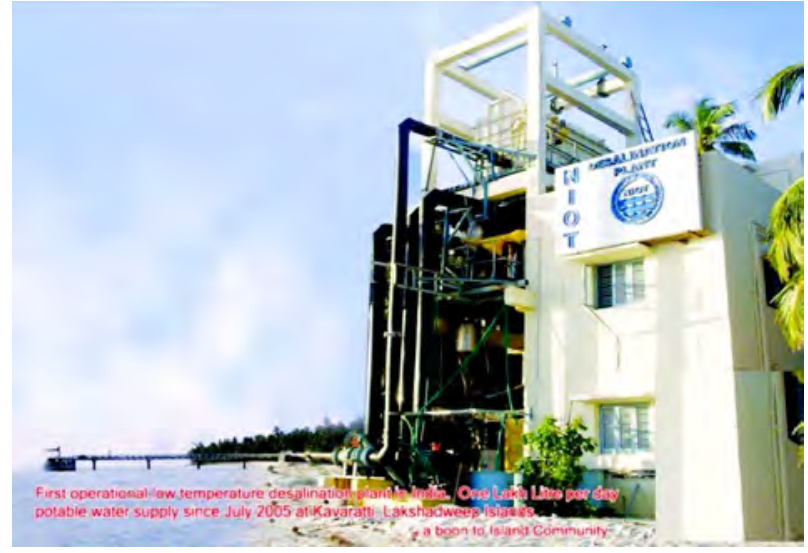

Fig. 7: One lakh litre per day LTTD plant at Kavaratti, Lakshadweep Islands

\section{References}

Avery W H (2002) Ocean thermal energy conversion. Encyclopedia of Physical Science and Technology, $3^{\text {rd }}$ editionVol 11 p 123

Brooke J (2003) Wave Energy Conversion Report of Engineering Committee on Oceanic Resources, Working group on wave energy conversion pp 204

Manivannan P, Soundrarajan D, Palaniappan M, Raja Abraham, Narayanan S, Muthukumaravel S, Vedhachalem N and Jayamani R (2003) OTEC developmental activities in India, Proc. Int. Conf. on Coastal and Ocean Engineering, NIOT, Chennai, India pp 371-381

Masuda Y and Miyazaki T (1978) Wave power electric generation study in Japan, Proc. Int. Symp. Wave Tidal Energy, 27-29 September, B6.65-B6.92

Raghunathan S (1985) Performance of the Wells self-rectifying turbine Aeronaut J 89 369-379

\section{Desalination}

Low temperature thermal desalination is actually a spin-off from the OTEC cycle. Whenever two bodies of water at different temperatures are available such as the surface and deep ocean waters, the temperature gradient can be utilized to generate fresh water.

NIOT carried out extensive laboratory studies and set up the first land-based demonstrative plant at Kavaratti in Lakshadweep with a capacity of 1 lakh litres per day. A long HDPE pipe was deployed in a special configuration successfully. The plant has been running continuously since 2005 fulfilling the needs of the 10,000 strong local communities. On seeing the success of this plant, NIOT was asked to setup more similar plants. Accordingly, the plants at Agatti \& Minicoy were also commissioned and are running successfully.

Implementation of the low temperature thermal desalination is a true case of translating complex engineering into a societal benefit. This has been a pioneering effort in the fresh water generation scene in any part of the world. Subsequently, NIOT has also demonstrated the technology on the same OTEC barge offshore in deep waters.

Ravindran M, Jayashankar V, Jalihal P and Pathak A G (1997) The Indian Wave Energy Programme - An overview TERI Inform Digest Energy 7 173-188

Ravindran M (1999) The Indian 1MW floating OTEC plant - an overview, Keynote address, Proc. Int OTEC/DOWA Conf, Imari, Japan, 31 October-2 November

Ravindran M, Raju Abraham and Shijo Zachariah (2007) Environmental friendly energy options for India J Environ Studies 64 709-718

Ravindran M (2010) Ocean Energy. In: Sustainable Energy in Asia and Pacific- Emerging Technologies and Research Priorities (Eds: MohdNordin Hasan and Sukanta Roy) Chapter 5, Academy of Sciences Malaysia, ICSU Regional Office for Asia and Pacific, Kuala Lumpur

Santha Kumar S, Jaya Sankar V, Atonanand M R, Ravindran M and Setoguchi T (1998) Performance of an impulse turbine based wave energy plant Proc ISOPE pp75-80 
Setoguchi T, Santha Kumar S, Macda H, Takkao M and Kanako K (2001) A review of impulse turbine for wave energy conversion Renew Energy 23 261-292

Sharma H R (1983) Tidal power civil structures - some engineering aspects Proc. Second National Conference in Ocean Engineering, Pune, December

Sharmila N, Purnima J, Swamy A K and Ravindran M (2004) Wave powered desalination system Renew Energy 29165172

Thorpe T W (1999) An overview of wave energy technologies states, performance and costs Proc. Conference on Wave power: Moving towards commercial viability 30 November, Institute of Mechanical Engineers, Westminister, London

Wilson E M (1973) Energy from the sea-Tidal power Underwater J 5 175-186.

\section{Websites/Reports}

1. www.aie.org.an/factsheet 10

2. www.nationmaster.com-encylopedia:tidalpower

3. www.monsterandcrities.com/new/india-india news7/12/07

4. www.findarticles.com "Business Network 2003"

5. Report of 'Global Energy Network -Library' - on 'Asia Pacific' dated 04/05/2007

6. www.Crest-enerst.com

7. info@ powerinc.org on Pacific Ocean wave energy research

8. www.Vbresearch.com, sector focus: marine power

9. ieexplore.ieee.org/muetze.a,vining.j.g, 'ocean wave energy conversion' - A survey. 